\title{
A study of the structural chemistry of coesite
}

\author{
By G. V. GiBвs \\ Department of Geological Sciences, Virginia Polytechnic Institute and State \\ University* \\ and C. T. Prewit' and K. J. BALDWIN
}

Department of Earth and Space Sciences, State University of New York**

(Received 26 April 1976)

\begin{abstract}
Auszug
Wegen ihrer hohen Symmetrie weisen die meisten $\mathrm{SiO}_{2}$-Modifikationen nur wenige unabhängige ( $\mathrm{Si}-\mathrm{O})$-Abstände auf. Jedoch die Struktur des Coesits enthält zwei unabhängige $\mathrm{SiO}_{4}$-Tetraeder, acht (Si-O)-Bindungen, fünf $(\mathrm{Si}-\mathrm{O}-\mathrm{Si})$ - und zwölf $(\mathrm{O}-\mathrm{Si}-\mathrm{O})$-Winkel und bietet sich somit als ein ausgezeichnetes Objekt zur Prüfung der Theorie der ( $\mathrm{Si}-\mathrm{O}$ )-Bindungen an. Um den bestmöglichen Satz von $(\mathrm{Si}-\mathrm{O})$-Abständen zu erhalten, haben die Verfasser die Struktur eines synthetischen Kristalls bis zu $R=0,024$ verfeinert. Die Gitterkonstanten dieses Kristalls sind: $a=7,135(1), b=12,372(1), c=7,173(1)$, $\beta=120,36(1)^{\circ}$.

Eine Elektronenpopulations-Analyse nach Mulliken wurde unter Annahme einer mittleren Länge von 1,614 $\AA$ für alle ( $\mathrm{Si}-\mathrm{O}$ )-Bindungen berechnet bei Verwendung sowohl der von Araki und Zoltai 1969 gefundenen Valenzwinkel $(R=0,076)$ als auch von denjenigen der vorliegenden Untersuchung. Es zeigte sich, daß die Überlappungsdichten der ( $\mathrm{Si}-\mathrm{O}$ )-Bindungen, die aus den neuen Koordinatenwerten berechnet wurde, den beobachteten Bindungslängen besser korreliert sind als die sich aus den älteren Werten ergebenden Dichten $\left(r^{2}=0,91\right.$ gegenüber $\left.r^{2}=0,60\right)$. Das ist ein Hinweis darauf, daß für eine lineare Korrelation zwischen Bindungs-Überlappung und -Länge genaue Strukturdaten erforderlich sind. Die individuellen ( $\mathrm{Si}-\mathrm{O})$-Abstände verhalten sich nicht-linear in bezug auf die ( $\mathrm{Si}-\mathrm{O}-\mathrm{Si}$ )-Winkel, jedoch linear in bezug auf $-1 / \cos (\mathrm{Si}-\mathrm{O}-\mathrm{Si})$, wobei kürzere Bindungen größeren Winkeln $\mathrm{Si}-\mathrm{O}-\mathrm{Si}$ und $\mathrm{O}-\mathrm{Si}-\mathrm{O}$ entsprechen. Die Ergebnisse der Untersuchung zeigen, daß es im Coesit keine Abweichung von der stöchiometrischen Zusammensetzung gibt, daß keine ungewöhnliche Wärmeschwingung des O-Atoms in der linearen Bindung $\mathrm{Si}-\mathrm{O}-\mathrm{Si}$ vorhanden ist und daß die Schwankungen der individuellen (Si-O)-Abstandslängen eng mit der beobachteten Bindungsüberlappung, den gegenseitigen Abstoßungen der nicht-gebundenen Atome und der Ladung des O-Atoms zusammenhängt.
\end{abstract}

* Blacksburg, Virginia.

** Stony Brook, N.Y. 


\begin{abstract}
Because of their high symmetry, most of the silica polymorphs contain only a few nonequivalent $\mathrm{Si}-\mathrm{O}$ distances. However, the structure of coesite contains two nonequivalent silicate tetrahedra, eight $\mathrm{Si}-\mathrm{O}$ bonds, five $\mathrm{Si}-\mathrm{O}-\mathrm{Si}$ and twelve $\mathrm{O}-\mathrm{Si}-\mathrm{O}$ angles. thus making it an excellent candidate for testing $\mathrm{Si}-\mathrm{O}$ bonding theory. In order to obtain the best possible set of $\mathrm{Si}-\mathrm{O}$ distances, we refined the structure using single-crystal diffraction data from a synthetic crystal (unweighted $R=0.024$ ). Cell parameters for this crystal are $a=7.135(1) \AA, b=12.372(1), c=7.173(1)$, and $\beta=120.36(1)$.

A Mulliken population analysis was calculated with all $\mathrm{Si}-\mathrm{O}$ bond lengths clamped at $1.614 \AA$ and using the valence angles determined by ARAKI and ZoLTAI (1969) for which $R=0.076$, and those obtained from the present experiment. The $\mathrm{Si}-\mathrm{O}$ bond overlap populations calculated using the valence angles ()btained for the new coordinates were found to be more highly correlated $\left(r^{2}=0.91\right.$ vs. $r^{2}=0.60$ for the older data) with the observed $\mathrm{Si}-\mathrm{O}$ bond lengths, suggesting that precise structural data are necessary to obtain a nearlinear correlation between bond-overlap population and bond length. The individual $\mathrm{Si}-\mathrm{O}$ bond lengths to the oxygen in the $\mathrm{Si}-\mathrm{O}-\mathrm{Si}$ linkages in coesite vary (1) non-lineary when plotted against $\mathrm{Si}-\mathrm{O}-\mathrm{Si}$ angle and (2) linearly when plotted against $-1 / \cos \Varangle(\mathrm{Si}-\mathrm{O}-\mathrm{Si})$, shorter bonds being associated with wider angles. Shorter bonds also tend to be involved in the wider O-Si--() angles. The results of this experiment show that there is no evidence for departure from stoichiometry, that there is no unusual thermal vibration of the wxygen atom in the linear $\mathrm{Si}-\mathrm{O}-\mathrm{Si}$ linkage, and that variations in individual $\mathrm{Si}-\mathrm{O}$ distances are closely related to calculated bond-overlap populations, to the geminal nonbonded repulsions and to the charge of the oxygen atom.
\end{abstract}

\title{
Introduction
}

CRUICKSHANK (1961) has asserted from symmetry considerations that the orbitals comprising the $\sigma$ framework of a silicate ion may be neglected and that the $\mathrm{Si}-\mathrm{O}$ bond-length variations, $d(\mathrm{Si}-\mathrm{O})$, in silicates may be rationalized in terms of a $\pi$ system comprising the $3 d$ orbitals on $\mathrm{Si}$ and the $2 p$ orbitals on oxygen. Using an algorithm based on simple valence-bond theory, he calculated larger $\pi$-bond orders for $\mathrm{Si}-\mathrm{O}$ bonds involved in wider $\mathrm{Si}-\mathrm{O}-\mathrm{Si}$ angles, a result which implies that wider angles should involve shorter bonds. BRown, GibBs and Ribie (1969) have since presented a scatter diagram of $d(\mathrm{Si}-\mathrm{O})$ versus $\Varangle(\mathrm{Si}-\mathrm{O}-\mathrm{Si})$ for the silica polymorphs which seemed to support the prediction. Two years later, BAUR (1971) noted that the keatite data used by Brown et al. (1969) were too imprecise and that the tridymite data were not corrected for thermal motion. This warranted a reexamination of the correlation. Using corrected $\mathrm{Si}-\mathrm{O}$ bond-length and angle data for tridymite and uncorrected bond-length data for the remaining silica polymorphs and for four pyrosilicates, 
BAUR undertook a weighted linear regression analysis that indicated that the correlation between $d(\mathrm{Si}-\mathrm{O})$ and $\Varangle(\mathrm{Si}-\mathrm{O}-\mathrm{Si})$ might not exist and that CRUICKSHANK's $\pi$-bonding model should be reevaluated as a general bonding theory for the silicates. Later that year, the relationship between $d(\mathrm{Si}-\mathrm{O})$ and $(\mathrm{Si}-\mathrm{O}-\mathrm{Si})$ angle was examined again by TAYLOR (1972), who used only data for the silica polymorphs. After correcting all the $\mathrm{Si}-\mathrm{O}$ distances for the thermal motion of the oxygen atoms, he calculated a regression line for $d(\mathrm{Si}-\mathrm{O})$ versus $\mathrm{Si}-\mathrm{O}-\mathrm{Si}$ angle. The resulting line was found to be less steep than that obtained earlier by Brown et al. (1969) but statistically identical with the one calculated by Gibbs, Hamil, Louisnathan, Bartell and Yow (1972). More recently, Meagher and Gibbs (1976) completed a weighted linear regression analysis on the $d(\mathrm{Si}-\mathrm{O})$ and $\Varangle \mathrm{Si}-\mathrm{O}-\mathrm{Si}$ data for the five silica polymorphs studied by BAUR (1971); the data for the four pyrosilicates were excluded because their bond-length data were considered to belong to a population distinct from that of the silica polymorphs. The analysis yielded a linear correlation coefficient of $r=-0.44$ and permitted Meagher and Gibis to reject the null hypothesis that there is no relationship between $d(\mathrm{Si}-\mathrm{O})$ and $\Varangle \mathrm{Si}-\mathrm{O}-\mathrm{Si}$ for the five silica polymorphs at the 0.001 level.

Recent $a b$ initio calculations by Collins, Cruickshank and BreEze (1972) using a limited basis set have indicated that there is considerable $\mathrm{Si}(3 d)$-orbital involvement in the wavefunction of the silicate ion. On the other hand, SCF $\mathrm{X} \alpha$ scattered-wave calculations published by Tossell, Vaughan and Johnson (1973) for the silicate ion and SCF calculations by Gilbert, Stevens, Schrenk, Yoshimine and BAGUs (1973) for a linear $\mathrm{Si}_{2} \mathrm{O}$ molecule indicate that the $3 d$ orbitals make a somewhat smaller contribution to the wavefunctions for the silicate ion. In 1972, GiBBs et al. completed two sets of semiempirical molecular-orbital calculations (with and without $3 d$ orbitals) to learn whether the steric details of isolated and polymerized silicate ions in ten minerals might be rationalized in terms of a covalent model. When all the $\mathrm{Si}-\mathrm{O}$ bond lengths were clamped at $1.63 \AA$, all the $\mathrm{O}-\mathrm{Si}-\mathrm{O}$ and $\mathrm{Si}-\mathrm{O}-\mathrm{Si}$ valence angles were clamped at observed values and all the nontetrahedral cations were ignored, the calculated bond overlap populations, $n(\mathrm{Si}-\mathrm{O})$, were found to correlate with the observed bond lengths, shorter bonds tending to be involved with larger $n(\mathrm{Si}-\mathrm{O})$ values. Furthermore, it was discovered in a study of the feldspars (Gibis, Louisnathan, Ribbe and Phillips, 1974) that the model predicts essentially identical trends in bond-length and 
valence-angle variations whether or not the $3 d$ orbitals on Si are included in the calculations. This result is consistent with the assertion that experimental evidence like bond-length and valence-angle correlations cannot be used as evidence to prove whether $3 d$ orbitals are involved in bonding between $\mathrm{Si}$ and $\mathrm{O}$ any more than they can be used to prove whether the $s$ and $p$ orbitals are involved (Mitchell, 1969; Bartell, Su and Yow, 1970). Since Gibbs et al. (1972) ignored the nontetrahedral cations in their calculations, it is not surprising that only about 60 percent of the variation in $d(\mathrm{Si}-\mathrm{O})$ could be explained in terms of a linear dependence on $n(\mathrm{Si}-\mathrm{O})$. To determine whether improved correlations may be obtained for silicates which lack nontetrahedral cations, $n(\mathrm{Si}-\mathrm{O})$ values were calculated for the silica polymorph coesite. We selected coesite to test this possibility because, unlike the other known silica polymorphs, it contains two nonequivalent silicate tetrahedra with eight nonequivalent $\mathrm{Si}-\mathrm{O}$ bond lengths and it shows a relatively wide range in $\mathrm{Si}-\mathrm{O}-\mathrm{Si}$ angles from $138^{\circ}-180^{\circ}$. In addition, each of its oxygen atoms is two-coordinated and bridges two silicate tetrahedra. Accordingly, all the bonds are $\mathrm{Si}-\mathrm{O}(\mathrm{br})$ bonds requiring that the sum of the Pauling valence-bond strength to each oxygen be exactly two. It is impossible, therefore. to rationalize the observed bond-length to valence-angle variations in terms of BAUR's $(1970 ; 1971)$ extended electrostatic-valence rule. Since coesite lacks nontetrahedral cations, the bond-length variations should be related to variations in the valence angles within and between the silicate tetrahedra. Our first calculations for coesite were completed several years ago (unpublished) using the ARAKI and ZoLtaI (1969) atomic coordinates and the procedure outlined in the NATO feldspar volume (GIBbs et al., 1974). In the calculations all the $\mathrm{Si}-\mathrm{O}$ distances were clamped at $1.614 \AA$ but the observed valence angles within and between the tetrahedra were assumed. Since the participation of the $3 d$ orbitals in the wavefunctions of the silicate ion may be small, a minimum-valence basis set was used in all of our calculations. The resulting $n(\mathrm{Si}-\mathrm{O})$ values are plotted in Fig. 1 against the observed $\mathrm{Si}-\mathrm{O}$ bond lengths. Although the correlation is negative, it is clear that the scatter of the data about the regression line is fairly large. Indeed, the scatter is similar to that obtained in similar calculations for the feldspars (GIBBs et al., 1974) where the neglect of the nontetrahedral cations may be expected to have contributed to the spread of data points. However, since coesite lacks nontetrahedral cations, the scatter of the data in Fig. 1 suggests 


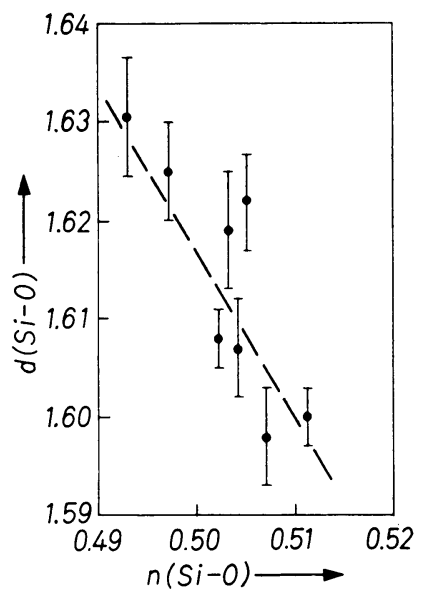

Fig. 1. A scatter diagram of the observed $\mathrm{Si}-\mathrm{O}$ bond lengths, $d(\mathrm{Si}-\mathrm{O})$, in coesite determined by Araki and Zoltai (1969) vs. the $\mathrm{Si}-\mathrm{O}$ bond overlap populations, $n(\mathrm{Si}-\mathrm{O})$, calculated assuming all the $\mathrm{Si}-\mathrm{O}$ bond lengths equal to $1.614 \AA$ and using the observed valence angles within and between the silicate tetrahedra. The vertical bars drawn through each data point mark off one estimated standard deviation in the observed $\mathrm{Si}-\mathrm{O}$ bond length. The dashed line was calculated by a weighted linear regression analysis

that either the covalent-bonding model is deficient or that the ArAKI and ZoLTAI (1969) structural refinement is too imprecise to yield an improved correlation. To resolve this problem, we collected a new set of intensity data for coesite, calculated a refinement of its structure and compared the resulting bond-length and valence-angle data with the results provided by a Mulliken population analysis.

\section{Experimental}

The coesite crystal selected for the single-crystal analysis was grown at $65 \mathrm{kbar}$ and $110^{\circ} \mathrm{C}$. It is approximately equi-dimensional ( $\sim 0.2 \mathrm{~mm}$ in diameter) without plane faces. Precession photographs are consistent with the space group $C 2 / c$ previously determined by Zoltai and Buerger (1959) and Araki and Zoltai (1969). The cell parameters refined by least squares using 19 single-crystal reflections are given in Table 1 along with those determined by Araki and ZoltaI. The differences in reported cell parameters may be a result of experimental errors or differences in stoichiometry, as discussed by Araki and Zoltai. It should be noted, however, that the $\beta$ angle of the coesite cell determined in our work is the first to be reported as statistically different from $120^{\circ}$. 
The reflection intensities were measured using the $\theta-2 \theta$ scan technique with two 20 -second background counts for each peak and a scan speed of $1^{\circ}$ per minute. Peak position and intensity data were obtained with a Picker single-crystal diffractometer using $M o K \alpha$ $\mathrm{x}$-radiation and a graphite monochromator. In all, 941 reflections were measured, 805 of which were considered to be significantly above background. Details of the weighting scheme used for least-squares structure refinement and data reduction are given in PrewitT and Sleight (1968). No corrections were made for $x$-ray absorption.

Table 2 gives the final refinement results obtained using the computer program RFINE written by Dr. L. Finger. The unweighted

Table 1. Cell parameters for coesite

\begin{tabular}{|c|c|c|c|c|c|}
\hline Reference & $a$ & $b$ & $c$ & $\beta$ & $V$ \\
\hline $\begin{array}{l}\text { ARAKI and } \\
\text { ZOLTAI }(\mathbf{1 9 6 9 )}\end{array}$ & $7.173(4) \AA$ & $12.328(6) \AA$ & $7.175(4) \AA$ & $120.0^{\circ}$ & $549.5 \AA^{3}$ \\
\hline This work & $7.135(1)$ & $12.372(1)$ & $7.174(1)$ & $120.36(1)$ & $546.4(3)$ \\
\hline
\end{tabular}

Table 2. Atom coordinates and temperature factors $\left(\times 10^{5}\right)$ for coesite*

\begin{tabular}{|c|c|c|c|c|c|c|c|}
\hline & \multicolumn{2}{|c|}{$x$} & \multicolumn{3}{|c|}{$y$} & \multicolumn{2}{|l|}{$z$} \\
\hline $\operatorname{Si}(1)$ & \multicolumn{2}{|c|}{$0.14027(7)$} & \multicolumn{3}{|c|}{$0.10838(3)$} & \multicolumn{2}{|c|}{$0.07234(7)$} \\
\hline $\operatorname{Si}(2)$ & \multicolumn{2}{|c|}{$0.50658(7)$} & \multicolumn{3}{|c|}{$0.15796(4)$} & \multicolumn{2}{|c|}{$0.54049(7)$} \\
\hline $\mathrm{O}(1)$ & \multicolumn{2}{|l|}{0} & \multicolumn{3}{|c|}{0} & \multicolumn{2}{|l|}{0} \\
\hline $\mathrm{O}(2)$ & \multicolumn{2}{|c|}{0.5} & \multicolumn{3}{|c|}{$0.11608(14)$} & \multicolumn{2}{|c|}{0.75} \\
\hline $\mathrm{O}(3)$ & \multicolumn{2}{|c|}{$0.2660(2)$} & \multicolumn{3}{|c|}{$0.12327(11)$} & \multicolumn{2}{|c|}{$0.9400(2)$} \\
\hline $\mathrm{O}(4)$ & \multirow{2}{*}{\multicolumn{2}{|c|}{$0.3110(2)$}} & \multirow{2}{*}{\multicolumn{3}{|c|}{$\begin{array}{l}0.10374(11) \\
0.21188(10)\end{array}$}} & \multirow{2}{*}{\multicolumn{2}{|c|}{$\begin{array}{l}0.3280(2) \\
0.4784(2)\end{array}$}} \\
\hline $\mathrm{O}(5)$ & & & & & & & \\
\hline & $\beta_{11}$ & $\beta_{22}$ & $\beta_{33}$ & $\beta_{12}$ & $\beta_{13}$ & $\beta_{23}$ & $B_{\text {eq }}$ \\
\hline $\mathrm{Si}(1)$ & $339(11)$ & $66(3)$ & $352(11)$ & $-32(4)$ & $188(9)$ & $-24(4)$ & $0.52 \AA^{2}$ \\
\hline $\operatorname{Si}(2)$ & $359(11)$ & $77(3)$ & $318(11)$ & $-3(4)$ & $191(9)$ & $-14(4)$ & 0.49 \\
\hline $\mathrm{O}(1)$ & $477(38)$ & $98(10)$ & $575(40)$ & $-90(15)$ & $219(33)$ & $-28(16)$ & 0.88 \\
\hline $\mathrm{O}(2)$ & $625(40)$ & $113(10)$ & $881(37)$ & 0 & $385(33)$ & 0 & 0.99 \\
\hline $\mathrm{O}(3)$ & $508(28)$ & $154(7)$ & $637(30)$ & $-63(12)$ & $424(25)$ & $-27(12)$ & 0.89 \\
\hline $\mathrm{O}(4)$ & $593(29)$ & $155(8)$ & $356(27)$ & $-70(11)$ & $119(24)$ & $-35(11)$ & 0.98 \\
\hline $\mathrm{O}(5)$ & $566(28)$ & $66(7)$ & $731(32)$ & $-2(11)$ & $357(24)$ & 14(11) & 0.78 \\
\hline
\end{tabular}

$*$ estimated standard deviations are given in parentheses. $B_{\mathrm{eq}}=\frac{4}{3} \sum_{i} \sum_{j} a_{i} a_{j} \beta_{i j}$ 
$R$ for all observed reflections is 0.024 and the weighted $R$ is 0.037 . Araki and Zoltai reported that they had difficulty in refining anisotropic temperature factors; however, no such difficulty was encountered in our calculations and it must be assumed that some kind of systematic error was present in their data or structure model. The equivalent isotropic temperature factors in both refinements are somewhat larger than expected; this may be a result of imperfection introduced in the crystals on quenching from high pressure.

The interatomic distances, the valence angles and their estimated standard deviations calculated from the results of our refinement are given in Table 3 . The differences between these values and those previously published by ARAKI and ZoLTaI are small but significant. Liebau (1961) noted that the $\mathrm{Si}-\mathrm{O}-\mathrm{Si}$ angle of $180^{\circ}$ might be an average caused by $\mathrm{O}(1)$ statistically occupying two lower-symmetry positions on either side of the center of symmetry. If this were true, the $\mathrm{O}(1)$ temperature factor should be anomalously larger than those of the other oxygen atoms. However, this is not the case; the $B$ value for $O(1)$ is actually smaller than those calculated for $O(2), O(3)$ and $\mathrm{O}(4)$.

\section{Molecular orbital calculations}

The electronic population parameters for the atoms in coesite (Table 3) were estimated using a modified version of Hoffmann's extended Hückel molecular orbital (EHMO) program. In the program, the overlap integrals, $S_{i j}$, between the $i$ th and $j$ th valence atomic orbitals are explicitly evaluated even for next-nearest-neighbor atoms, the Coulomb integrals $h_{i i}$ are set equal to the negative of the valenceorbital ionization potentials (VOIP) and the resonance integrals $h_{i j}$ are set equal to the parameterization $S_{i j}\left(h_{i i}+h_{j j}\right)$. Following the construction and solution of the secular determinant, the program computes the electronic-population parameters by completing a Mulliken population analysis (1955). The VOIP's and the exponents for the Slater-type atomic orbitals used as input in our calculations are given in Table 4. An inherent flaw in the EHMO method is that the resulting energies and wavefunctions are highly dependent on the form of the parameterization. On the other hand, $\mathrm{BASCH}$ et al. (1965) have shown that trends in bond-overlap populations and electric charges for a series of chemically and structurally related molecules are virtually independent of the exact parameterization. Hence, it is the correlations that seem to be significant, not the absolute numbers. We believe that 
Table 3. Bond lengths, interbond angles, and Mulliken population parameters for coesite

\begin{tabular}{r|c|c|c|c}
\hline Atom pair & Distance & $n(\mathrm{Si}-\mathrm{O})$ & $n b(\mathrm{Si}-\mathrm{O})$ & $Q(\mathrm{O})$ \\
\hline $\mathrm{Si}(1)-\mathrm{O}(1)$ & $1.5950(4) \AA$ & 0.512 & -0.086 & -1.223 \\
$-\mathrm{O}(3)$ & $1.613(1)$ & .503 & -0.091 & -1.246 \\
$-\mathrm{O}(4)$ & $1.610(1)$ & .506 & -0.089 & -1.241 \\
$-\mathrm{O}(5)$ & $1.621(1)$ & .495 & -0.094 & -1.254 \\
& $<1.6014(3)>^{*}$ & & & \\
$\mathrm{Si}(2)-\mathrm{O}(2)$ & $1.6126(7)$ & 0.500 & -0.090 & -1.245 \\
$-\mathrm{O}(3)$ & $1.615(1)$ & .502 & -0.091 & \\
$-\mathrm{O}(4)$ & $1.604(1)$ & .504 & -0.090 & \\
$-\mathrm{O}(5)$ & $1.618(1)$ & .500 & -0.092 & \\
& $<1.6124(4)>$ & & &
\end{tabular}

Atom pair

Around $\mathrm{Si}(1)$

$O(1)-O(3)$
$-O(4)$
$-O(5)$
$O(3)-O(4)$
$-O(5)$
$O(4)-O(5)$

Distance

$$
2.634(1) \AA
$$

$2.613(1)$

$2.633(1)$

$2.646(2)$

$2.615(2)$

$2.629(2)$

$<\overline{2.6273}(5)>$
$\mathrm{O}-\mathrm{Si}-\mathrm{O}$ angle

\begin{tabular}{|c|}
\hline $110.41(6)^{\circ}$ \\
\hline $109.26(5)$ \\
\hline $109.90(5)$ \\
\hline $110.41(7)$ \\
\hline $107.93(7)$ \\
\hline $108.90(7)$ \\
\hline
\end{tabular}

Around $\mathrm{Si}(2)$

$$
\begin{array}{r}
O(2)-O(3) \\
-O(4) \\
-O(5) \\
O(3)-O(4) \\
-O(5) \\
O(4)-O(5)
\end{array}
$$

$$
\begin{aligned}
& 2.637(1) \AA \\
& 2.623(1) \\
& 2.650(2) \\
& 2.619(2) \\
& 2.638(2) \\
& 2.629(2) \\
&<\overline{2.6313}(6)>
\end{aligned}
$$

$$
\begin{aligned}
& 109.58(6)^{\circ} \\
& 109.30(7) \\
& 110.22(8) \\
& 108.94(7) \\
& 109.39(7) \\
& 109.38(7) \\
& <\frac{109.45(3)}{}>
\end{aligned}
$$

\begin{tabular}{l|c|c}
\hline & $\mathrm{Si}-\mathrm{Si}$ distance & Angle \\
\hline $\mathrm{Si}(1)-\mathrm{O}(1)-\mathrm{Si}(1)$ & $3.190(1) \AA$ & $180^{\circ}$ \\
$\mathrm{Si}(2)-\mathrm{O}(2)-\mathrm{Si}(2)$ & $3.055(1)$ & $142.52(13)$ \\
$\mathrm{Si}(1)-\mathrm{O}(3)-\mathrm{Si}(2)$ & $3.073(1)$ & $144.39(10)$ \\
$\mathrm{Si}(1)-\mathrm{O}(4)-\mathrm{Si}(2)$ & $3.101(1)$ & $149.54(9)$ \\
$\mathrm{Si}(1)-\mathrm{O}(5)-\mathrm{Si}(2)$ & $3.016(1)$ & $137.29(9)$ \\
& $<\overline{3.0870}(4)>$ &
\end{tabular}

* weighted average with e.s.d.'s in parentheses. 
Table 4. Valence orbital ionization potentials (VOIP) and orbital exponents ( $\zeta$ )

\begin{tabular}{c|c|c|c}
\hline Atom & Atomic orbital & VOIP & $\zeta$ \\
\hline \multirow{2}{*}{ Oxygen } & $2 s$ & $-32.33 \mathrm{eV}$ & 2.246 \\
& $2 p$ & -15.79 & 2.226 \\
Silicon & $3 s$ & -14.83 & 1.634 \\
& $3 p$ & -7.75 & 1.428
\end{tabular}

EHMO results (bond-overlap populations, geminal antibonding-overlap populations and electric charges) can be useful in ordering bondlength and valence-angle variations but they cannot be used in any sense to prove the experimental data. We also believe that the interplay between molecular orbital and experimental results can serve to improve our understanding of the crystal chemistry of minerals by yielding important information about their electronic structures and the nature of the bonding forces involved.

\section{Discussion}

The silicate tetrahedra in coesite are arranged in a complicated way to form a framework structure that bears a topological resemblance to that of feldspar (Zoltai and Buerger, 1959; Megaw, 1970). ('hains of four-membered rings of silicate tetrahedra along [010] are cross-linked to form "corrugated layers" of crankshaft chains paralleling [110]. However, unlike feldspar the linkage between the corrugated layers is affected by straight $\mathrm{Si}-\mathrm{O}-\mathrm{Si}$ bonds, resulting in a denser arrangement of tetrahedra. The two nonequivalent silicate tetrahedra in coesite, $\mathrm{Si}(1) \mathrm{O}_{4}$ and $\mathrm{Si}(2) \mathrm{O}_{4}$, are nearly regular with $d(\mathrm{Si}-\mathrm{O})$ ranging between 1.595 and $1.621 \AA$ and $\mathrm{O}-\mathrm{Si}-\mathrm{O}$ angles ranging between $108.9^{\circ}$ and $110.4^{\circ}$. Despite the small variation in $d(\mathrm{Si}-\mathrm{O})$, a surprisingly strong correlation $(r=-0.95)$ obtains between $d(\mathrm{Si}-\mathrm{O})$ and $n(\mathrm{Si}-\mathrm{O})$ calculated assuming a constant $\mathrm{Si}-\mathrm{O}$ distance $=1.614 \AA$ and using the angles within and between the silicate tetrahedra determined in this study (Fig. 2). The maximum deviation of any point from the regression line is $0.004 \AA$ with the average deviation being about $0.003 \AA$. This result suggests that the ARAKI and ZoltaI refinement of the structure of coesite is too imprecise to yield a similar correlation between $d(\mathrm{Si}-\mathrm{O})$ and $n(\mathrm{Si}-\mathrm{O})$. A comparison of the bondlength data obtained by Araki and Zoltai with that determined in this study shows that the two data sets are statistically identical with 


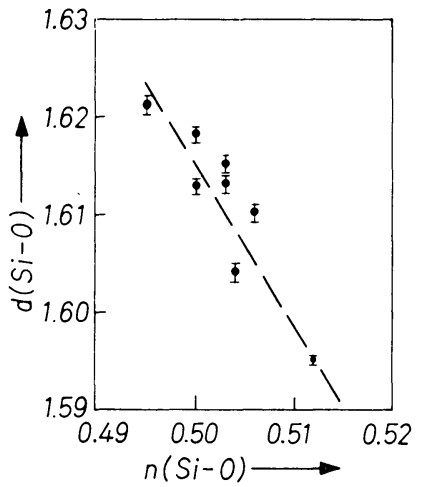

Fig. 2. A scatter diagram of the observed $\mathrm{Si}-\mathrm{O}$ bond lengths, $d(\mathrm{Si}-\mathrm{O})$. in coesite determined in this study $v s$. the $\mathrm{Si}-\mathrm{O}$ bond overlap population, $n(\mathrm{Si}-$ ()). calculated assuming all the the $\mathrm{Si}-\mathrm{O}$ bond lengths equal to $1.614 \AA$ and usin: the $\mathrm{O}-\mathrm{Si}-\mathrm{O}$ and $\mathrm{Si}-\mathrm{O}-\mathrm{Si}$ angles observed in this study. The vertical bar: drawn through each data point mark off one e.s.d. in the bond length. Th... regression line (dashed) was calculated in a weighted linear regression of $d(\mathrm{Si}-$ () on $n(\mathrm{Si}-\mathrm{O})$ where the inverse squares of the estimated standard deviations if the individual $\mathrm{Si}-\mathrm{O}$ bond lengths were used as weights. The null hypothe..that the value of the slope of the line, $b_{1}$, is zero [i.e., that there is no relatin... ship between $n(\mathrm{Si}-\mathrm{O})$ and $d(\mathrm{Si}-\mathrm{O})]$ may be rejected at the 0.001 level becan...

$$
t=b_{1} / \sigma\left(b_{1}\right)=33
$$

the exception of the $\mathrm{Si}(2)-\mathrm{O}(4)$ bond lengths which differ by more than three estimated standard deviations. It may be noted that the $n(\mathrm{Si}-\mathrm{O})$ value calculated for this bond from the angles determined by Araki and Zoltai indicates that the bond is too long and that it should be the shortest bond in the $\mathrm{Si}(2) \mathrm{O}_{4}$ tetrahedron rather than the longest one. In agreement with this indication, our refinement of the structure shows the $\mathrm{Si}(2)-\mathrm{O}(4)$ bond to be the shortest bond in the $\mathrm{Si}(2) \mathrm{O}_{4}$ tetrahedron. In fact, when a linear-regression analysis is completed using the $\mathrm{Si}-\mathrm{O}$ bond-length data observed in this study and the bond-overlap populations calculated for coesite using the valence angles determined by Araki and Zoltai (1969), a significant improvement in the correlation is obtained as evinced by the correlation coefficient of $r=0.89$. If this result is not fortuitous, it suggests that the $n(\mathrm{Si}-\mathrm{O})$ values calculated from the observed valence angles may serve as a crude test of the ordering of the bond lengths in the silicate tetrahedra for other silica polymorphs.

Since there is a strong correlation between $d(\mathrm{Si}-\mathrm{O})$ and $n(\mathrm{Si}-\mathrm{O})$ and since the observed valence angles were used in the calculations, 


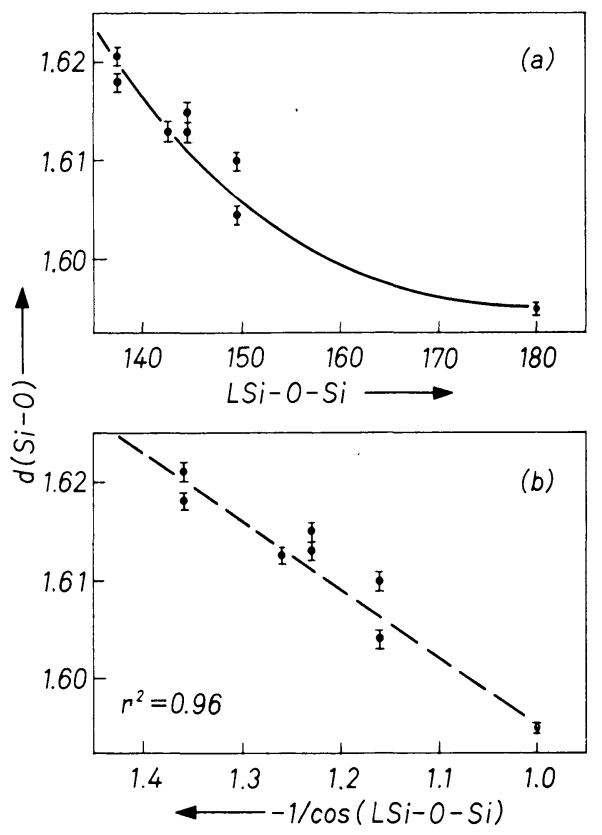

Fig. 3. Scatter diagrams of $d(\mathrm{Si}-\mathrm{O})$ vs. (a) $\mathrm{Si}-\mathrm{O}-\mathrm{Si}$ angle and $(b)-1 / \cos$ $\Varangle(\mathrm{Si}-\mathrm{O}-\mathrm{Si})$. A weighted linear regression analysis completed for $d(\mathrm{Si}-\mathrm{O}) v s$. $-1 / \cos \Varangle(\mathrm{Si}-\mathrm{O}-\mathrm{Si})$ yielded a correlation coefficient of $r=0.98$. Since Student's |t calculates to be 35 , the hypothesis that $d(\mathrm{Si}-\mathrm{O})$ might not be dependent on $-1 / \cos \Varangle(\mathrm{Si}-\mathrm{O}-\mathrm{Si})$ may be rejected at the 0.001 level

we may expect $d(\mathrm{Si}-\mathrm{O})$ to correlate with the valence angles within and between the silicate tetrahedra. The individual $\mathrm{Si}-\mathrm{O}$ bond lengths in coesite are plotted against $\Varangle \mathrm{Si}-\mathrm{O}-\mathrm{Si}$ and $-1 / \cos \Varangle$ ( $\mathrm{Si}-\mathrm{O}-\mathrm{Si}$ ) in Fig. 3 and against the average of the three $\mathrm{O}-\mathrm{Si}-\mathrm{O}$ angles common to the bond, $<\mathrm{O}-\mathrm{Si}-\mathrm{O}>_{3}$, in Fig. 4, shorter bonds in each case tending to involve wider angles. EHMO theory predicts that $n(\mathrm{Si}-\mathrm{O})$ should increase nonlinearly when plotted against $\Varangle \mathrm{Si}-\mathrm{O}-\mathrm{Si}$ and linearly when plotted against $-1 / \cos \Varangle(\mathrm{Si}-\mathrm{O}-\mathrm{Si})$ (GIBBs et al., 1972). Since $d(\mathrm{Si}-\mathrm{O})$ appears to vary linearly with $n(\mathrm{Si}-\mathrm{O})$, shorter bonds involving larger $n(\mathrm{Si}-\mathrm{O})$ values, the trends evinced by Fig. 3 are as expected. The theory also predicts that $<\mathrm{O}-\mathrm{Si}-\mathrm{O}>_{3}$ is a measure of the strength of the bond common to the three angles comprising $<\mathrm{O}-\mathrm{Si}-\mathrm{O}>_{3}$, larger $n(\mathrm{Si}-\mathrm{O})$ values tending to involve bonds with larger $<\mathrm{O}-\mathrm{Si}-\mathrm{O}>_{3}$ values. Despite the small range of $<\mathrm{O}-\mathrm{Si}-\mathrm{O}>_{3}$ angles $\left(108.9-109.9^{\circ}\right)$ exhibited by 


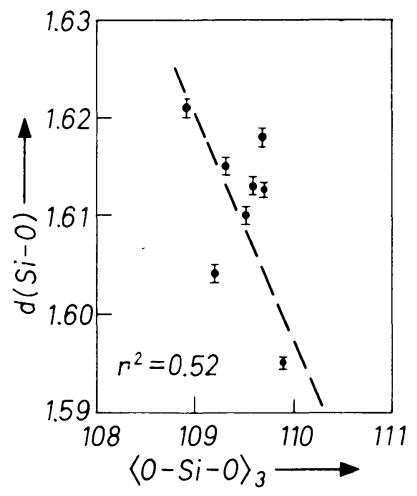

Fig. 4

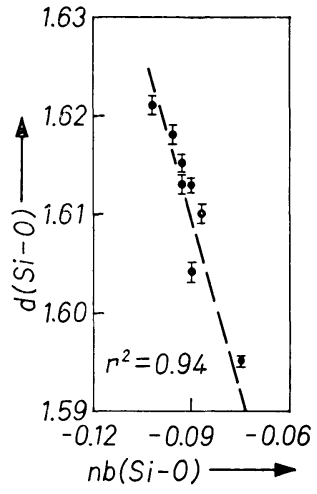

Fig. 5

Fig. 4. A scatter diagram of $d(\mathrm{Si}-\mathrm{O}) v s .<\mathrm{O}-\mathrm{Si}-\mathrm{O}>_{3}$, the mean $\mathrm{O}-\mathrm{Si}-\mathrm{O}$ angle common to the $\mathrm{Si}-\mathrm{O}$ bond. The hypothesis that $d(\mathrm{Si}-\mathrm{O})$ might not be dependent on $<\mathrm{O}-\mathrm{Si}-\mathrm{O}>_{3}$ may be rejected at the 0.001 level

Fig. 5. A scatter diagram of $d(\mathrm{Si}-\mathrm{O}) v s$. geminal nonbonding overlap populations, $n b(\mathrm{Si}-\mathrm{O})$, taken to equal the algebraic sum of all the antibonding populations across a $\mathrm{Si}-\mathrm{O}$ bond (BARTELl et al., 1970)

the silicate tetrahedra in coesite, a weighted regression analysis of the data plotted in Fig. 4 shows the correlation to be highly significant with shorter bonds tending to involve wider valence angles.

The $\mathrm{Si}-\mathrm{O}$ bond lengths in coesite also correlate with the geminal nonbonding overlap populations, $n b(\mathrm{Si}-\mathrm{O})$, taken to equal the algebraic sum of all antibonding populations across a $\mathrm{Si}-\mathrm{O}$ bond (Fig. 5). According to BARTELl et al. (1970), $n b(\mathrm{Si}-\mathrm{O})$ gives a measure of the repulsion forces that tend to stretch bonds as bond-overlap populations decrease. This assertion agrees with Fig. 6 which indicates that repulsion forces become more important as the angles between silicate tetrahedra narrow, as the $\mathrm{Si}-\mathrm{Si}$ separations decrease and as the nonbonding populations become more negative. Moreover, it appears that $n b(\mathrm{Si}-\mathrm{O})$ interactions may be as important as $n(\mathrm{Si}-\mathrm{O})$ interactions in governing trends in $\mathrm{Si}-\mathrm{O}$ bond-length variations in coesite. A similar conclusion was reached by BARTELL et al. (1970) in an EHMO examination of the tetrahedral bond-length variations in phosphate and sulfate tetrahedral oxyanions.

In addition to bonding- and nonbonding-overlap populations, EHMO theory also provides crude estimates of the electrical charges on the atoms in coesite. As observed for the feldspars, a correlation 


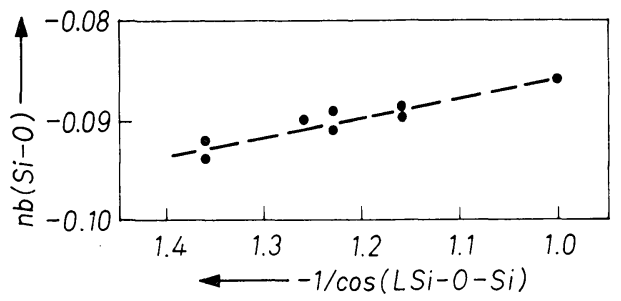

Fig. 6. A scatter diagram of geminal nonbonding overlap populations, $n b(\mathrm{Si}-\mathrm{O})$ vs. $-1 / \cos \Varangle(\mathrm{Si}-\mathrm{O}-\mathrm{Si})$
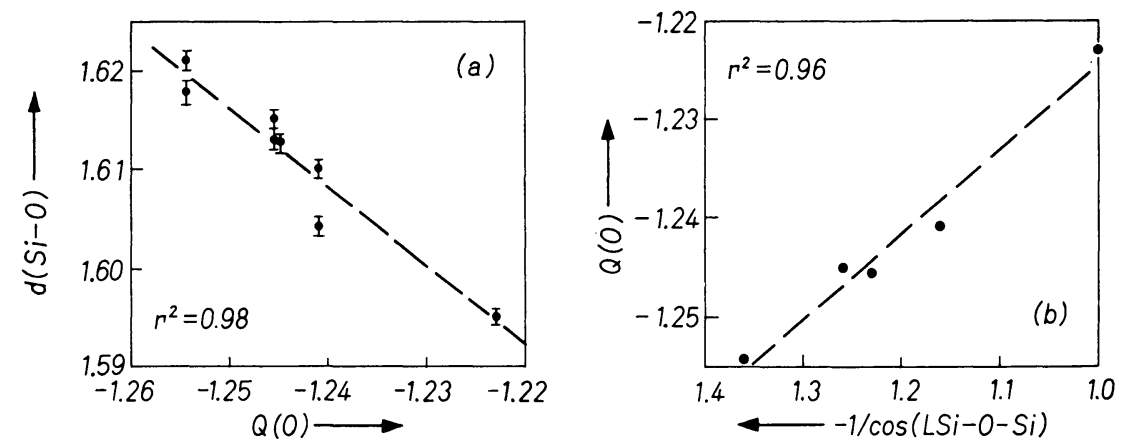

Fig. 7. Scatter diagrams of the EHMO electric charges, $Q(\mathrm{O})$, calculated for the oxygen atoms vs. $(a)$ the observed length of the $\mathrm{Si}-\mathrm{O}$ bond involving the oxygen atom and $(b)$ the $\mathrm{Si}-\mathrm{O}-\mathrm{Si}$ angle involving the oxygen atom

can be made between the electrical charges, $Q(\mathrm{O})$, calculated for oxygen and $d(\mathrm{Si}-\mathrm{O})$. As evinced by Fig. $7 a$, a well-developed correlation exists between $d(\mathrm{Si}-\mathrm{O})$ and $Q(\mathrm{O})$, with longer bonds involving oxygen atoms with larger charges. Since $d(\mathrm{Si}-\mathrm{O})$ is strongly correlated with the $\mathrm{Si}-\mathrm{O}-\mathrm{Si}$ angle, the correlation between $Q(\mathrm{O})$ and $\mathrm{Si}-\mathrm{O}-\mathrm{Si}$ angle is expected (Fig. $7 b$ ). Hence, EHMO theory predicts that longer $\mathrm{Si}-\mathrm{O}$ bonds involved in narrower $\mathrm{Si}-\mathrm{O}-\mathrm{Si}$ angles also involve the more highly charged oxygen atoms.

The weighted mean $\mathrm{Si}-\mathrm{O}$ bond length of the $\mathrm{Si}(1) \mathrm{O}_{4}$ tetrahedron is slightly but significantly shorter, $1.601 \AA$, than that of the $\mathrm{Si}(2) \mathrm{O}_{4}$ tetrahedron, $1.612 \AA$. Since the bonds in the $\mathrm{Si}(1) \mathrm{O}_{4}$ tetrahedron tend to be involved in wider $\mathrm{Si}-\mathrm{O}-\mathrm{Si}$ angles and longer $\mathrm{Si}-\mathrm{Si}$ distances, we may expect the $\mathrm{Si}(1) \mathrm{O}_{4}$ ion to possess shorter bond lengths on the average. 
Finally, it is well known that the observed $\mathrm{C}-\mathrm{C}$ bond-length data for such hydrocarbons as ethane, ethylene and acetylene may be ranked very nicely in terms of bond number and total bond order (Pauling, 1960; Coulson, 1961). Moreover, if EHMO calculations are completed for these same hydrocarbons assuming constant bond lengths, $d(\mathrm{C}-\mathrm{C})=1.43 \AA$ and $d(\mathrm{C}-\mathrm{H})=1.05 \AA$ and observed valence

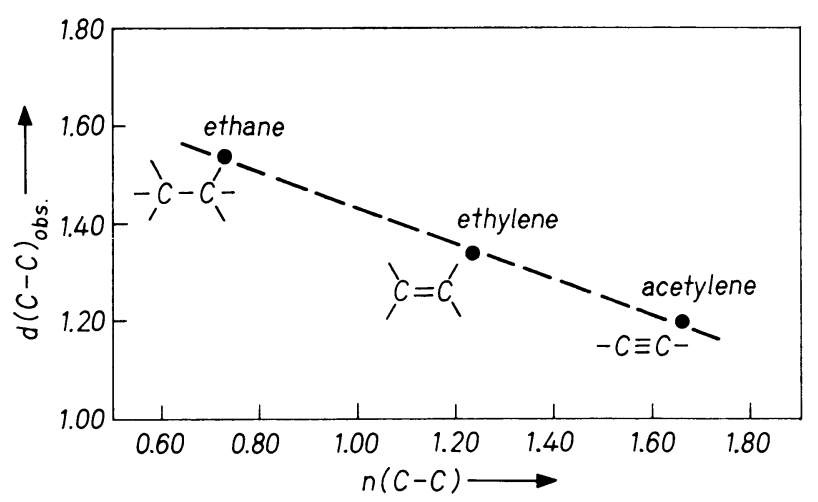

Fig. 8. A plot of the observed $\mathrm{C}-\mathrm{C}$ bond lengths, $d(\mathrm{C}-\mathrm{C})$, in ethane, $\mathrm{C}_{2} \mathrm{H}_{6}$, ethylene, $\mathrm{C}_{2} \mathrm{H}_{4}$, and acetylene, $\mathrm{C}_{2} \mathrm{H}_{2}$ vs. $n(\mathrm{C}-\mathrm{C})$ calculated assuming $d(\mathrm{C}-\mathrm{C})$ $=1.43 \AA, d(\mathrm{C}-\mathrm{H})=1.05 \AA$ and using the observed valence angles. It is generally asserted that the bond-overlap population relates to the electron density between bonded atoms, a larger overlap population implying a larger density in the region of the bond. If we consider the binding forces acting on the nuclei of the two bonded atoms, we may expect a large binding force and accordingly a shorter bond when the electron density in the bond is large. Since the Mulliken bond-overlap population is a crude measure of this electron density, the negative correlation observed between bond overlap population and bond length is expected

angles as done for coesite, we see that a strong correlation obtains between the observed $\mathrm{C}-\mathrm{C}$ bond length, $d(\mathrm{C}-\mathrm{C})$, and $n(\mathrm{C}-\mathrm{C})$, shorter bonds involving larger overlap populations as expected. Moreover, the $n(\mathrm{C}-\mathrm{H})$ values calculated for the $\mathrm{C}-\mathrm{H}$ bonds are constant for all three molecules, in agreement with the fact that these bonds have the same length in all three molecules. It is our belief that the correlations presented here and elsewhere between observed $\mathrm{Si}-\mathrm{O}$ bond length and $\mathrm{Si}-\mathrm{O}$ bond overlap populations have the same meaning and significance as that obtained for the hydrocarbons (Fig. 8). 


\section{Acknowledgments}

The Earth Sciences Section of the National Science Foundation is thanked for supporting this study with grant DES 75-14912 and grant A04-1137, and the Research Division at VPI \& SU is acknowledged for funds to use the University computer. Mr. A. Prunier is thanked for his assistance in preparing and running a number of the calculations. We also thank Mrs. Ramonda Haycocks for typing the manuscript and Mrs. Sharon Chiang for drafting the figures. Drs. E. P. Meagher and R. J. Hill gave the manuscript a constructive review.

\section{References}

T. Araki and T. Zoltai (1969), Refinement of a coesite structure. Z. Kristallogr. 129, $381-387$.

L. S. BARTEll, L. S. Su and H. Yow (1970), Lengths of phosphorus-oxygen and sulfur-oxygen bonds. An extended Hückel molecular orbital examination of Cruickshank's $d_{\pi}-p$ picture. Inorg. Chem. 9, 1903-1912.

H. Basch, A. Viste and H. B. Gray (1965), Valence orbital ionization potentials from atomic spectra data. Theoret. Chim. Acta 3, 458-464.

W. H. BAUR (1970), Bond length variation and distorted coordination polyhedra in inorganic crystals. Trans. Amer. Crystallogr. Ass. 6, 125-155.

W. H. BAUR (1971), The prediction of bond length variations in silicon-oxygen bonds. Amer. Mineral. 56, 1573-1599.

G. E. Brown, G. V. Gibbs and P. H. Ribbe (1969), The nature and variation in length of the $\mathrm{Si}-\mathrm{O}$ and $\mathrm{Al}-\mathrm{O}$ bonds in framework silicates. Amer. Mineral. 54, 1044-1061.

G. A. D. Collins, D. W. J. Cruickshank and A. Breeze (1972), Ab initio calculations on the silicate ion, orthosilicic acid and their $L_{2,3} \mathrm{x}$-ray spectra. J. Chem. Soc., Faraday Trans. II 68, 1189-1195.

C. A. Coulson (1961), Valence, 2nd edition, Oxford University Press, London.

D. W. J. Cruickshank (1961), The role of $3 d$-orbitals in $\pi$-bonds between (a) silicon, phosphorus, sulfur, or chlorine and $(b)$ oxygen or nitrogen. J. Chem. Soc., 5486-5504.

G. V. Gibbs, M. M. Hamil, S. J. Louisnathan, L. S. Bartell and H. Yow (1972), Correlations between $\mathrm{Si}-\mathrm{O}$ bond length, $\mathrm{Si}-\mathrm{O}-\mathrm{Si}$ angle and bond overlap populations calculated using extended Hückel molecular orbital theory. Amer. Mineral. 57, 1578-1613.

G. V. Gibbs, S. J. Louisnathan, P. H. Ribbe and M. W. Phillips (1974), Semiempirical molecular orbital calculations for the atoms of the tetrahedral framework in anorthite, low albite, maximum microcline and reedmergnerite. In: W. S. MacKenzie and J. Zussman (editors), The feldspars, Manchester University Press, Manchester, pp. 49-67.

T. L. Gilbert, W. J. Stevens, H. Schrenk, M. Yoshimine and P. S. Bagus (1973), Chemical bonding effects in the oxygen $K \alpha \mathrm{x}$-ray emission bands of silica. Physic. Rev. B 8, 5977-5998. 
F. Liebau (1961), Untersuchungen über die Größe des Si-O-Si-Valenzwinkels. Acta Crystallogr. 14, 1103-1109.

E. P. Meagher and G. V. Gibbs (1976), A molecular orbital interpretation of bond length variations in the silica polymorphs. Canadian Crystallogr. Conf., McMaster Univ., Hamilton, Ontario.

Helen D. Megaw (1970), Structural relationship between coesite and felspar. Acta Crystallogr. B 26, 261-265.

K. A. R. Mitchell (1969), The use of outer $d$ orbitals in bonding. Chem. Rev. 69, $157-178$.

R. S. MULliken (1955), Electronic population analysis on LCAO-MO molecular wave functions. I. J. Chem. Physics 23, 1833-1846.

Linus Pauling (1960), The nature of the chemical bond, 3rd edition, Cornell University Press, Ithaca, N.Y.

C. T. Prewitt and A. W. Sleight (1968), Structure of $\mathrm{Gd}_{2} \mathrm{~S}_{3}$. Inorg. Chem. 7, 1090-1093.

D. TAYLOR (1972), The relationship between $\mathrm{Si}-\mathrm{O}$ distances and $\mathrm{Si}-\mathrm{O}-\mathrm{Si}$ bond angles in the silica polymorphs. Mineral. Mag. 38, 629-631.

J. A. Tossell, D. J. Vaughan and K. H. Johnson (1973), X-ray photoelectron, $\mathrm{x}$-ray emission and $\mathrm{UV}$ spectra of $\mathrm{SiO}_{2}$ calculated by the $\mathrm{SCF} \mathrm{X} x$ scattered wave method. Chem. Physics Letters 20, 329-334.

T. Zoltai and M. J. Buerger (1959), The crystal structure of coesite. the dense, high-pressure form of silica. Z. Kristallogr. 111, 129-141. 